\title{
Perspectivas 2001
}

A cadeia produtiva do setor de polímeros está sendo profundamente analisada e discutida por diversas empresas e entidades da sociedade e, com a satisfação de quem está executando o dever de casa de forma coerente, os especialistas já apontaram claros gargalos do setor, bem como sugeriram possíveis ações para serem implementadas em futuro próximo. A BRASILPLAST, uma das exposições industriais de maior importância do País e terceira maior feira de plásticos do mundo, congrega não apenas

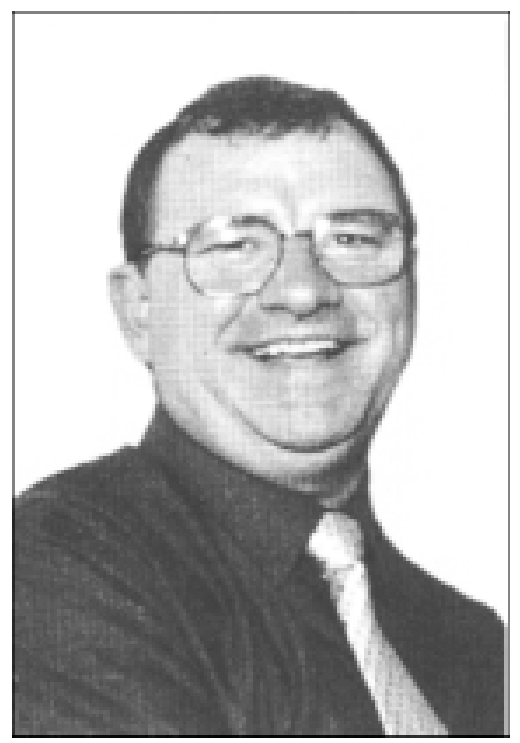

dústria, universidades e centros de P\&D nas atividades da ABPol, indo desde os eventos técnico-científicos até as atividades executivas, tem garantido ao longo dos anos a consolidação dos objetivos iniciais desta Associação. A cada dois anos são realizadas eleições de $50 \%$ dos membros do Conselho Diretor da $\mathrm{ABPol}$ e este processo terá início a partir de abril deste ano de 2001. É importante que os sócios participem ativamente, garantindo novamente uma votação com largas possibilidades de escolha, empresas que formam a cadeia produtiva do setor, como também as entidades que se dedicam às mais diversas atividades de interesse dos profissionais desse ramo.

Entidades como a ABPol, ABIPLAST, ABIQUIM, SIRESP, INP e entidades governamentais, entre outras, têm trabalhado de forma constante para garantir a estabilidade da cadeia produtiva dos materiais que mais têm crescido nos últimos anos.

Preocupada com um dos principais elos dessa cadeia, a ABPol sempre tem zelado pela interação entre indústria, universidades e centros de $\mathrm{P} \& \mathrm{D}$, de forma que a geração e disseminação do conhecimento fossem adequadamente acessadas por todos.

A participação equilibrada de profissionais da in- o que resultará na representatividade ideal do Conselho.

Outra atividade cujo processo está em andamento é a realização do $6^{\circ} \mathrm{CBPol}$ (Congresso Brasileiro de Polímeros) e IX Internacional Macromolecular Colloquium que ocorrerão de 11 a 15 de novembro próximo, em Gramado-RS. Com sucesso garantido, este evento já conta com diversas empresas patrocinando e se preparando para a exposição paralela que terá espaço exclusivo no Hotel Serrano. Como se trata do maior congresso brasileiro de polímeros a ocorrer conjuntamente com um tradicional evento internacional, é esperado que nesses quatro dias estejam presentes profissionais, pesquisadores e expositores das mais diversas áreas do setor de polímeros do mundo.

Silvio Manrich

Presidente 